\title{
Chodzić do kina
}

\section{MICHAŁ GŁOWIŃSKI}

Z najwcześniejszego dzieciństwa zapamiętałem przerwaną wyprawę do kina. To, że nie dotarliśmy do celu, $\mathrm{z}$ pewnością mocno mnie rozczarowało, skoro to wydarzenie mam w pamięci do dzisiaj. Była pełnia lata, wczesne popołudnie, chyba rok 1938 a może 1939. Wybieraliśmy się z Matką i z Babką do pruszkowskiego kina, które wówczas mieściło się w pałacyku Sokoła, mieliśmy obejrzeć Królewnę Śnieżkę. Ale gdy idąc sobie w ten piękny dzień spacerem, przechodziliśmy nieopodal stacji kolejowej, wyszedł z niej ktoś z bliskiej rodziny, który niespodziewanie, bez zapowiedzi, przyjechał z Warszawy w odwiedziny. Trzeba było zawracać. Z powodu takiego, jakże dla mnie niekorzystnego, biegu wydarzeń w kinie przed wojną nie byłem.

Oczywiście, lata okupacji stanowiły dla mnie czas bez kina. Nie tylko dlatego, że obowiązywał bojkot, lapidarnie zalecany w znanym sloganie „tylko świnie siedzą w kinie”. Brakowało po temu okazji, nawet gdyby chciano mnie na jakiś seans poprowadzić. W warszawskim getcie kina nie było, po stronie aryjskiej zaś miałem status zaszczutego żydowskiego dziecka, nie myślało się o rozrywkach, chodziło o życie. Na ogół zresztą przebywałem w miejscach, w których kina nie było - i nie ma go także dzisiaj.

Po raz pierwszy w roli widza wystąpiłem jesienią roku 1945, gdy dobiegałem jedenastego roku życia. Wówczas kino pruszkowskie wyniosło się z pałacyku „Sokoła”, wykorzystywanego do jakichś innych celów, mieściło się na ulicy Kraszewskiego i nie wiedzieć czemu nazywało się „Metro”. To w nim właśnie zobaczyłem rosyjski film pod tytułem Szyrmet-chan. Byłem zachwycony. Nie potrafię opowiedzieć jego fabuły, w każdym razie - nie mam w tej kwestii wątpliwości, gdy patrzę z odległej perspektywy - była to historia w stylu amerykańskich filmów z Dzikiego
Zachodu, $\mathrm{z}$ tą różnicą, że sławiła dzielnych carskich bojowników, walczących z barbarzyńskimi Azjatami i zdobywających nowe tereny dla rosyjskiego imperium. Dzisiaj pewnie bym powiedział, że to wytwór ideologii kolonialnej. Nie wiem, kiedy dzieło to wyprodukowano, nie jestem świadom, jak brzmi nazwisko reżysera. W wielotomowej historii filmu Jerzego Toeplitza, w której padają setki tytułów, o Szyrmet-chanie wzmianki nie ma, czemu trudno się dziwić.

W następnych latach byłem dość częstym gościem kina „Metro”, choć repertuar w pierwszej powojennej dekadzie był nader marny. Fascynacja sztuką filmową pozostała mi do dzisiaj. Nie przepadam za oglądaniem filmów w domu, lubię chodzić do kina $z$ różnych powodów, także dlatego, że to czas wydzielony z codzienności, na swój sposób odświętny. Kiedy przyglądam się publiczności, stwierdzam od wielu lat, że jestem na sali widzem najbardziej wiekowym. Starsi państwo wolą oglądać filmy, siedząc w fotelu przed telewizyjnym ekranem.

Sierpień 2010 